\title{
Restriction Enzyme Mapping
}

National Cancer Institute

\section{Source}

National Cancer Institute. Restriction Enzyme Mapping. NCI Thesaurus. Code C17094.

Use of restriction endonucleases to generate a physical map of genomes, genes, or other segments of DNA. 